\title{
History of Local Wisdom of Ikan Larangan Lubuak Landua as Environmental Conservations
}

\author{
Misbahul Janatti \\ Civic Education \\ Universitas Pendidikan Indonesia \\ Bandung, Indonesia \\ misbahuljanatti@student.upi.edu
}

\begin{abstract}
Every local wisdom in a society has a history, where local wisdom is still upheld by the adherents who passed down from generation to generation. Ikan larangan is one of local wisdom where river is protected through according to local custom. Ikan larangan is used to protect fish that are around the river ban. The purpose of this study was to determine the history of how the Ikan larangan lubuak landua as an effort to preserve the environment. This research uses qualitative method-case study with data collection technique by interview, observation, and documentation. The results showed that the Ikan larangan lubuak landua has a history starting from Sheikh Muhammad Basjirs until now Sheikh Mustafa Kamal and fish ban made tourist attraction. The existence of Ikan larangan has provided benefits that is to maintain the sustainability of fish resources, maintain the cleanliness of the river and increase the economy of the community around the prohibition of the ban by establishing a shop selling drinks and snacks for the visitors Ikan larangan.
\end{abstract}

Keywords-local wisdom; fish prohibition; culture society; environmental preservation

\section{INTRODUCTION}

Minangkabau society is one of the most famous ethnic communities in Indonesia which certainly has a unique culture when compared with other tribal communities [1]. Local wisdom is a system in the social, cultural, political and economic life, and environment that lives in the local community. Research on local wisdom of good value, embedded and followed by community members into traditions, customs.

Local wisdom can be encountered in various aspects of life such as Ikan Larangan (IL) or Lubuak Larangan (LL). Almost all areas in western Sumatra have IL [2]. Diversity of fish contained in LL [3]. The ikan larangan will be harvested at a predetermined time and limiting the type of fishing gear [4]; [5]. LL is a form of local wisdom that aims to preserve the river area [6]; [7]. Determination of ikan larangan by deliberation, readings of Surat Yasin 125 times by 40 people in Masjid [8]. River to the extent of daily necessities, the fulfillment of life but used for comfort, tranquility and tranquility with the symbols and philosophy of life in an aphorism "merusak alam, bermakna membinasakan diri sendiri" [9]. LL conservation examples based on local knowledge of the community to the environment [10]. With this ikan larangan will have a positive impact on the environment, the sustainability of the fish in the river [11]. Communities who violate the results of deliberations that have been settled will be subject to sanctions, if the offense is a customary leader are subject to sanctions doubled from the general public [12]. This research is different from what has been done before, where the IL made tourist attraction has a long history.

\section{STUdy LITERATURE}

\section{A. Local Wisdom}

Local wisdom comes from two words of wisdom and local. in general, local wisdom is the ideas or ideas of local ideas that are wise, full of wisdom, good value, embedded and followed by members of the community who embraces local wisdom into traditions, customs and daily behaviors in form with a long period of time, inherited from generation to generation so as to form the values of custom and tradition distinct from a distinct group of people with other communities [13], [14]. Local wisdom is often referred to as local genius, Wales suggests the local genius [15]; [16]; [17]; [18]; [19]; [20]; [21]. As a system of local knowledge, local wisdom distinguishes one local community from another. Local wisdom has benefits for: a) Conservation and conservation of natural resources, b) Developing human resources, c) Cultural and scientific development, and d) Advice, trust, literature, and abstinence [22].

\section{B. Ikan larangan}

The LL consists of two words namely the lubuak and the Larangan. The Lubuak itself is a deep part of a river, which is generally a breeding ground for fish, while a Larangan is a rule that prohibits an act. So, the meaning of the lubuak larangan is an area of a river that is naturally a breeding place for fish or other aquatic biota, in that area is a forbidden area for fish and other biota to be taken within a certain period of time. This area is managed by the community through the Nagari regulations. In line with the definition of LL certainly has an IL in it. IL area is protected by law both criminal law and social law. The people who violate this regulation such as stealing the fish will be fined in accord with prevailed regulation. In some areas, people are afraid to take the fish because the mythos and belief 
held from generation to generation. They believe that act of stealing the fishes can cause suffering or disaster [23].

\section{Environmental Conservation}

Talking about the environment is closely related to the empowerment of natural resources, human resources and artificial resources, if not managed properly will cause an imbalance. Article 33, paragraph 3 "... earth, water and space and natural resources contained therein for the greatest possible prosperity of the society ..." [24]. To preserve the environment, need to conserve the environment, such as the conservation done with local wisdom such as LL or IL made by society [25].

\section{Culture Society}

Culture or known by the word culture comes from Sanskrit, the word Buddhayah. The word Buddhayah is the plural form of the Buddhi word which means as the matter of the mind of man. In English, culture is called a culture, the word culture itself comes from the Latin word Colere which means the maintenance, management and cultivation of land into agricultural land. culture is one way of life that is developed and shared by a group of people passed down from generation to generation as a human creation which is really only the result of his efforts to change and give new forms and arrangements to nature, according to his physical and spiritual needs. It is the culture which aims to satisfy a series of needs of the human instincts that relate to the whole of its life or in other words can be defined as the whole complex of knowledge, belief, art, morals, laws, customs and all other abilities and habits acquired by a person as a member of society [26]; [27]; [21]; [28]; [17].

Culture as a result of a process of human effort in overcoming the limitations in life, where in the culture contained cultural values that can shape human character. Through the process of human learning produces culture [29]. Humans as social beings become producers of systems of thinking, values, morals, norms, and beliefs; but also, in interaction with fellow human beings and the realm of life, man is governed by the system of thinking, values, morals, norms, and beliefs he has produced [30]. Culture is defined as a symbol and meaning in a society, in which there are norms and values about social relations and behavior that becomes the identity of the community concerned [31].

Culture is the whole process and activity of thought and the result of effort or human mind that is understood and lived and belongs together through the learning process to overcome the limitations of human beings in maintaining and facilitating the existence of his life [32].

Every society has a culture, however simple the culture is and every human being is a civilized being [33]. The existing culture will continue to develop in accordance with the era because of the transformation of the culture itself. Efforts to transform natural facts into facts of culture, power of concrete work in the form of human thinking (thinking), human feel (feeling), human imagining, perceiving, interpreting, with such things will color the cultural characteristics of a group human or society [34].
Culture can be divided into three kinds of views of the circumstances and types namely:

- Human life-instinct, that is, cause the peaceful order of community life with its subtle and beautiful customs; the peaceful order of the government of the country; the peaceful order of religion and the science of instinct and decency, and the harmonization between soul and body.

- The human imagination, which can lead to the nobleness of language, literature and decency.

- Human intelligence, which gives rise to a variety of versatility about land companies, commerce, crafts, shipping, traffic relationships, various types of arts are all beautiful [35].

With the diversity of cultures that exist in Indonesia then established national culture as an identity of Indonesian culture as stipulated in Article 32 of the 1945 Constitution "The State promotes the national culture of Indonesia in the midst of world civilization by ensuring the freedom of society in maintaining and developing its cultural values, the state respects and maintains the regional language as the national cultural treasure" [24].

\section{METHODOLOGY}

This research uses a qualitative- case study approach is a study that seeks to understand and interpret the meaning of an interaction event of human behavior in certain situations from the perspective of the researcher himself. Data collection techniques in this study with interviews, observation, and documentation. This study uses primary data obtained from indepth interviews with key informants individually. In addition to using in-depth interviews, researchers also conducted observations to the field, so that the results of research really accurate and reliable. Informant research is determined by using purposive sampling technique with the consideration to meet the needs of the desired data in accordance with research objectives. This study aims to collect data or information from community groups who understand or are involved in the management of prohibition holes.

\section{RESULT}

Several areas in West Sumatra have an IL tradition, the village elders agreed to forbid the fish to be caught within a few months to preserve the fish and preserve the hereditary traditions. It is said that ikan larangan should not be arrested, if arrested and eaten will cause death, sick, at least the belly swelled because it has done the cleric. Ikan larangan should only be caught when clerics who forbid fishing catch pray blessing over the fish, so it is allowed to be caught and eaten. This below is a picture of the IL or LL lubuak landua: 


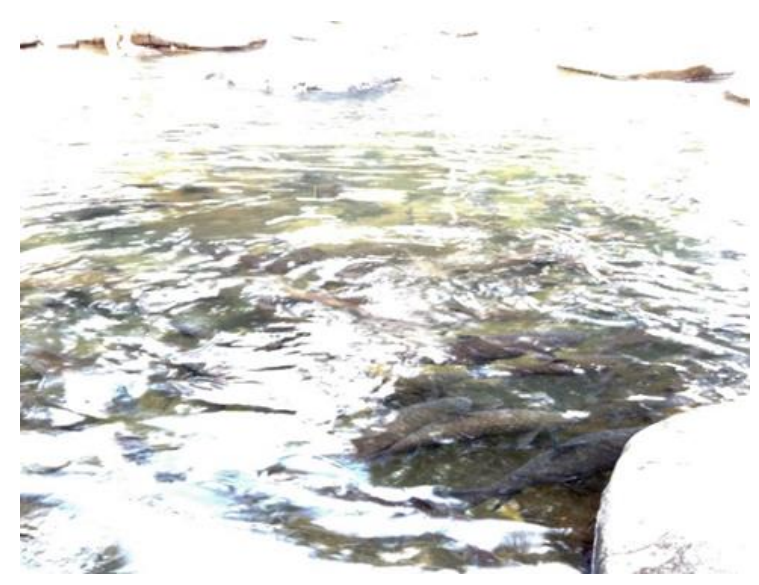

Fig. 1. IL lubuak landua.

a. Provenience: Personal Documentation.

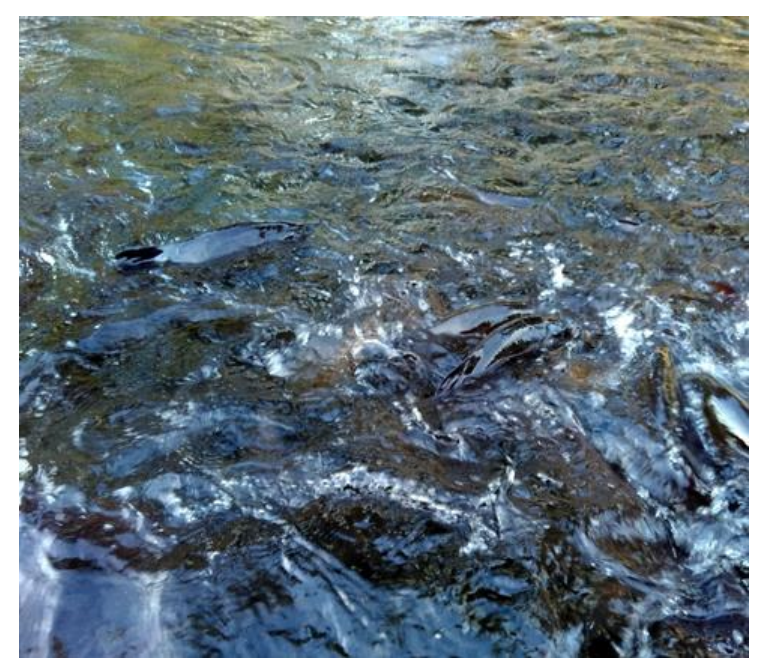

Fig. 2. IL lubuak landua.

${ }^{\mathrm{b} .}$ Provenience: Personal Documentation

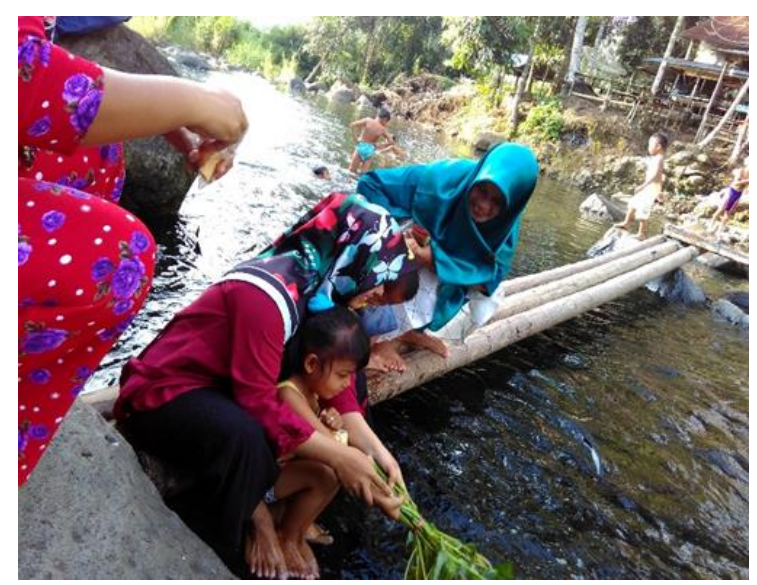

Fig. 3. The community feeds the IL lubuak landua.

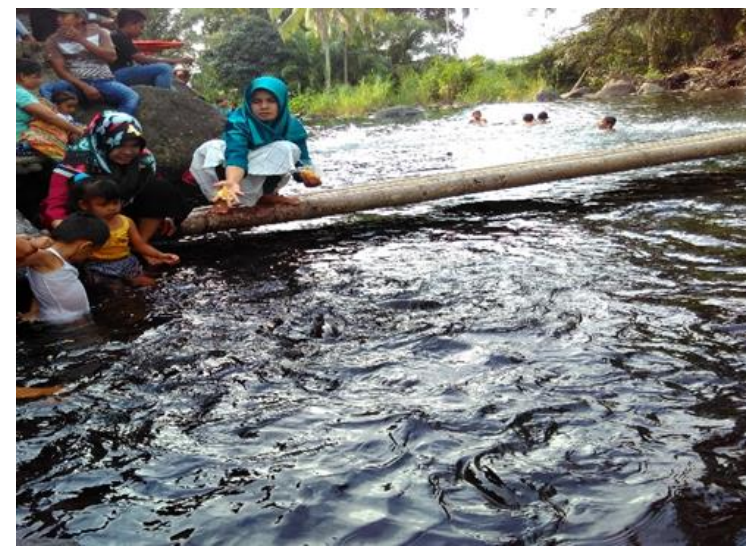

Fig. 4. The community feeds and swim with the IL lubuak landua.

d. Provenience: Personal Documentation

IL on the edge of Surau (mosque) lubuak landua different from the IL in general that exist in western Sumatra, which has a long history. The IL from the land of Sheikh Muhammad Basjir's relics was summoned by the Almighty before he could bless the blessing and the permissibility of the fishing of the ban, after which he was allowed to be caught, Buya Lubuak Landua (BLL) substituted him saying that Sheikh Muhammad Basjir did not leave the will allow the fish to be caught. That's what caused the IL big, many and benign.

IL become one of the tourist attractions crowded visited by the public. These fishes have been hundreds of years old at the same age as mosque. IL is a river fish in the grocer by feeding and should not be taken according to community agreement. The people are landscape religious, from the story of the first spreading of the first religion in Pasaman Barat. This history is proved by a Surau or old mosque that still stands firmly, estimated age of this mosque about 155 years. Mosque with walled and boarded boards, built on Samad's land, has a Mantiko Lenggang custom in $1800 \mathrm{M}$ by Sheikh Muhammad Basjir (1800 M - 1920 M) who is a nephew of Mantiko Lenggang tribe with Malay. During his youth Muhammad Basjir was a young warrior and a lover of science, he was interested in studying the Tariqat, and traveled to Makkatul Mukarramah, he met with Sheikh Abdu Ar-Rahman in Jabal Qubis, studied the Naqsyabandiyah Thariqat and obtained diplomas and permission from Sheikh Abdu Ar -Rahman to lead and develop the Naqsyabandiyah Thariqat. Returning to the hometown of Sheikh Muhammad Basjir, developed the Naqsyabandiyah Thariqat when he was 26 years old.

He was assigned the land by his tribe mamak (uncle) Mantiko Lenggang to establish a surau place persuluakan (meditate), since then mosque visited and used many people who study the science of Naqsyabandiyah Thariqat, ranging from the indigenous people Lubuak Landua, Batang Saman, Muara Kiawai even up to North Sumatra. Sheikh Muhammad Basjir, Buya Lubuak Landua I. The extension of mosque was continued during the time of BLL II, Sheikh Muhammad Amin (1920 M - 1927 M) son of Shaykh Muhammad Basjir resumed in BLL III, Sheikh Abdul Majid (1927 M - 1984 M) son of Shaykh Muhammad Amin. In 1984 M Syeik Abdul Majid 
passed away, the leadership of Thariqat Naqsyabandiyah continued by his younger brother named Sheikh Abdul Jabar (1984 M - 1991 M), titled BLL IV. The expansion of the surau continued, even during the time of BLL V Syeikh Bahri (1991 M - 2008 M) of the sons of Sheikh Abdul Jabar, mosque increasingly widespread only had one peak mosque, increased to four peak mosques. The expansion of the mosque stopped in $2000 \mathrm{M}$. The land of mosque is now about 300 meters.

Although mosque is expanded and repaired, the mosque buildings remain walled and boarded, to preserve the mosque historical value and maintain the comfort of the assembly Suluak. Now mosque is led by Mr. Muzardin son of Sheikh Abdul Majid. He is known as Sheikh Mustafa Kamal with BLL VI (2008 M - now). Mosque remains crowded by assembly Tariqat Naqsyabandiyah, who want to carry out suluak and pilgrimage to tomb BLL, which deliberately is buried south of mosque. Mosque brings blessings to the residents around, because beside the mosque flowing river containing IL, natural attractions for children. IL is a lot, big and very benign, supposedly the story is hundreds of years old with the age of mosque.

\section{DISCUSSION}

Local wisdom is a potential factor in supporting the sustainability of natural resource management. Local wisdom arises from issues of public concern for environmental damage caused by the exploitative industrial impacts [36]. Humans who are aware of the significance of nature for their life will utilize it as needed and create a variety of rules or methods to keep its balance always maintained or sustained [37]. Ikan larangan as a form of local wisdom that exists in the government community to guarantee the local wisdom. Article 19 paragraph 1. The Regional Government recognizes the values of local wisdom possessed by the community in the management of fish resources in mainland public waters in the form of IL or LL. 2. The IL or LL as referred to in paragraph (1) have an impact on the conservation of fish resources, the economy of society and the environment. 3. An IL or LL in accordance with certain criteria may serve as a conservation area with a zoning system in order to preserve the diversity of fish species in a water and to save local species from becoming extinct. 4. Local Government in order to preserve and increase the availability of fish resources can conduct restocking in public waters. Community participation in conserving and developing fish existence is provided in Article 42 paragraph 1. The community may participate in assisting the supervision and protection of fish resources through a community-based monitoring system implemented by a community watchdog group. 2. In the context of improving and empowering community participation in supervision and protection of fish resources as referred to in paragraph (1), local governments encourage the growth and development of community groups of supervisors and customary groups LL [38]. In contrast to the prohibited fish contain in Jambi, rights and the responsibility for the management of the IL or LL is entirely in the hands of women's groups. This woman's authority has also been recognized by the Village Government [39].

\section{CONCLUSION}

Local wisdom exists in society manifested in resource conservation practices indicates that local people have knowledge in resource management and control over the utilization of existing resources. This is because they directly have an interest in those resources. This local knowledge is dynamic. The dynamics of local knowledge of the community in terms of management of fishery natural resources illustrates that culture is dynamic and functional in the life of the community. LL is one form of resource management derived from local knowledge of the Minang community in West Sumatra. IL or LL in addition to having ecological functions also have economic, social and cultural functions. As a form of local knowledge, LL on the way experiencing dynamics. The dynamics in LL occur because of changes in resources, religion and government systems. This LL can be an ingredient in the development of natural resource management or environmental preservation.

\section{ACKNOWLEDGMENT}

The author would like to thank Lembaga Pengelola Dana Pendidikan (LPDP) or Institution for Educational Fund Management of Republic of Indonesia which had gave financial support in following this international conference.

\section{REFERENCES}

[1] Widyanti A, Susanti L, Zahedi I, Muslim K. Ethnic differences in Indonesian anthropometry data: Evidence from three different largest ethnics. Int J Ind Ergon. 2015;47:72-78. doi:10.1016/j.ergon.2015.02.008.

[2] Aldeva Ilhami R. Inventory of Ikan Larangan: Local Wisdom from West Sumatra Supporting Contextual Science Learning in Indonesia. In: TaWei Hung, Shih Chien University Chian-Son Yu SCU, ed. Vol 1. Tokyo: Global Academic-Industrial Cooperation Society; 2017.

[3] Sari D, Zakaria IJ, Novarino W, Hewan LE, Biologi J, Tepian LL. Journal of Biological Sciences. 2016;85(2):82-85.

[4] Susyati Fratama Putri. Budaya Menangkap Ikan di Lubuk Larangan (Studi Kearifan Lokal pada Masyarakat Desa Pangkalan Indarung Kecamatan Singingi Kabupaten Kuantan Singingi. 2016;3(1):1-14.

[5] Lenny S. Syafei. Penebaran Ikan Untuk Pelestarian sumberdaya Perikanan. 2005;5.

[6] Maulana Firdaus dan Hakim Miftakhul Huda. PENGELOLAAN SUMBERDAYA IKAN DI SUNGAI SELATAN , PROVINSI ... 2017;(April). doi:10.15578/marina.v1i1.1026.

[7] Susilowati I. AN ANALYSIS OF CO-MANAGEMENT FISHERIES IN WEST SUMATRA PROVINCE, INDONESIA : A CASE STUDY OF IKAN LARANGAN.

[8] Pawarti A, Purnaweni H, Anggoro D. Nilai Pelestarian Lingkungan dalam Kearifan Lokal Lubuk Larangan Ngalau Agung di Kampuang Surau Kabupaten Dharmasraya Provinsi Sumatera Barat. 2012;(September):98-103.

[9] Dani AP, Nugroho F, Amrifo V. Kearifan Lokal Lubuk Larangan sebagai Upaya Pelestarian Sumberdaya Perairan di Nagari Sikucur Kecamatan V Koto Kampung dalam Kabupaten Padang Pariaman Provinsi Sumatera Barat. 2016;44(2).

[10] Yuliaty C, Priyatna N. LUBUK LARANGAN: DINAMIKA PENGETAHUAN LOKAL MASYARAKAT DALAM PENGELOLAAN SUMBER DAYA PERIKANAN PERAIRAN SUNGAI DI KABUPATEN LIMA PULUH KOTA Lubuk Larangan: 
Local Community Knowledge Dynamics of Inland Fisheries Resources Management in Lima Puluh Kota Regency. 2014:115-125.

[11] Reza Shah Pahlevi. Cultivation in the Districts of Pasaman and Padang Pariaman , West Sumatra Province. 1995;(3):7-12.

[12] Kurniasari N, Yulisti M. LUBUK LARANGAN: BENTUK PERILAKU EKOLOGIS MASYARAKAT LOKAL DALAM PENGELOLAAN SUMBER DAYA PERIKANAN PERAIRAN UMUM DARATAN ( TIPOLOGI SUNGAI ) Lubuk Larangan : Form of Ecological Behavior of Local Community in The Inland Fisheries Resource Management ( River Tipology ). 2013:241-249.

[13] Juniarta HP, Susilo E, Primyastanto M. Kajian profil kearifan lokal masyarakat pesisir pulau gili kecamatan sumberasih kabupaten probolinggo jawa timur. 2013;1(1):11-25.

[14] Nawangsih. Nilai kearifan lokal kawasan wisata menggunakan pendekatan. 2017. 7:57-65.

[15] Qodariah L. Nilai-Nilai Kearifan Lokal Masyarakat Adat Kampung Naga sebagai Alternatif Sumber Belajar. 2013;10(1):10-20.

[16] Dasrun Hidayat. Permainan tradisional dan kearifan lokal kampung dukuh garut selatan jawa barat. 2013;05(02):1057-1070.

[17] Yunus R. NILAI-NILAI KEARIFAN LOKAL ( LOCAL GENIUS ) SEBAGAI PENGUAT KARAKTER BANGSA. Yogyakarta: Deepublish; 2014.

[18] Christeward Alus. PERAN LEMBAGA ADAT DALAM PELESTARIAN KEARIFAN LOKAL SUKU SAHU DI DESA BALISOAN KECAMATAN SAHU KABUPATEN HALMAHERA BARAT. 2014;III(4):1-16.

[19] Fajarini U. Peranan kearifan lokal dalam pendidikan karakter. 2014.

[20] Sukmayadi T. Kajian tentang karakter berbasis nilai-nilai kearifan lokal pada masyarakat adat kampung kuta kecamatan tambaksari kabupaten ciamis. civicus. 2016;13

[21] Darmawan IWTM dan C. Civic Culture Dalam Nilai-Nilai Budaya Dan Kearifan Lokal Masyarakat Bali Aga Desa Trunyan I Wayan Trisna Mahardika, Cecep Darmawan. 2016;23(1).

[22] Mohammad Dokhi Dkk. ANALISIS KEARIFAN LOKALDITINJAU DARI KERAGAMAN BUDAYA. PDSPK Kemendikbud RI; 2016.

[23] Putri SF. Budaya Menangkap Ikan Dilubuk Larangan (Studi Kearifan Lokal pada Masyarakat Desa Pangkalan Indarung Kecamatan Singingi Kabupaten Kuantan Singingi). 2016;3(1):2016.

[24] Undang-Undang Dasar Negara Republik Indonesia Tahun 1945.

[25] Husni Thamrin. Kearifan Lokal dalam Pelestarian Lingkungan ( The Lokal Wisdom in Environmental Sustainable ). 2013;16:46-59.
[26] Margaretha L, Sundawa D. Pelestarian Nilai-Nilai Civic Culture dalam Memperkuat Identitas Budaya Masyarakat: Makna Simbolik Ulos dalam Pelaksanaan Perkawinan Masyarakat Batak Toba di Sitorang. 2016;3(3):64-72.

[27] Suwarna. Khasanah Budaya Nusantara. Pertama. Yogyakarta: Histokultura; 2016.

[28] Hana Mauludea, Nurhadianto I. BUDAYA MASYARAKAT SUKU TALANG MAMAK DALAM BAGIAN CIVIC CULTURE cara menggali nilai-nilai dalam kebudayaan suku Talang Mamak sebagai bagian. 2016;14, No.1:53-68.

[29] Ade Putra Panajaitan DKK. KORELASI KEBUDAYAAN \& PENDIDIKAN (Membangun Pendidikan Berbasis Budaya Lokal). Jakarta: Yayasan Pustaka Obor Indonesia; 2014.

[30] Koentjaraningrat. KEBUDAYAAN MENTALITAS DAN PEMBANGUNAN. cet. 21. Jakarta: PT. Gramedia; 2015.

[31] Sugiarti \& Trisakti Handayani. Kajian Kontemporer Ilmu Budaya Dasar. Malang: UMM Press; 1999.

[32] F.X. Rahyono. KEARIFAN BUDAYA DALAM KATA. cet. I. Jakarta: Penerbit Wedatama Widya Sastra; 2009.

[33] T.O. Ihromi. Pokok-Pokok Antropologi Budaya. cet. 14. (T.O. Ihromi, ed.). Jakarta: Yayasan Pustaka Obor Indonesia; 2016.

[34] Mardimin J. JANGAN TANGISI TRADISI. Yogyakarta: PENERBIT KANISIUS; 1994.

[35] Ki Hadjar Dewantara. Kebudayaan. cet. 5. Majelis luhur persatuan tamansiswa: Universitas Sarjanawiyata Tamansiswa (UST-Press); 2013.

[36] Nursyirwan Effendi. Kearifan lokal menuju penguatan karakter sosial: suatu tantangan dari kemajemukan budaya di sumatera barat. 2013:107115.

[37] Pahrudin HM. Urgensi Revitalisasi Kearifan Lokal di Tengah Ancaman Bencana Alam di Indonesia. 2011;598:250-257.

[38] Gubernur Sumatera Barat. PERATURAN DAERAH PROVINSI SUMATERA BARAT NOMOR 4 TAHUN 2012 TENTANG PENGELOLAAN DAN PERLINDUNGAN SUMBER DAYA IKAN. 2012.

[39] Agung Wiyono, Eddy Harfia surma, Effi Permatasari, Fredy Wahon Helmi, Julmansyah, Marzoni, Melky Koli Baran, Mustafal Hadi TE. Kehutanan Multipihak Langkah Menuju Perubahan. (Elizabeth Linda Yuliani, Djuhendi Tadjudin, Yayan Indriatmoko Dani W. Munggoro, Farid Gaban FM, ed.). Bogor: Perpustakaan Nasional Indonesia; 2006. 